\title{
Histopathological Studies on the Effects of the Ethanolic Extract of the fruits of Garcinia kola on Selected Organs of the Dog
}

\author{
Estudio Histopatológico del Efecto de los Extractos Etanólicos \\ de los Frutos de Garcinia kola en Órganos Seleccionados de Perro \\ "Nottidge H. O.; "Omobowale T. O. ; "Taiwo V. O. \& ** Omotoso M. A.
}

NOTTIDGE, H. O.; OMOBOWALE, T. O.; TAIWO, V. O. \& OMOTOSO, M. A. Histopathological studies on the effects of the ethanolic extract of the fruits of Garcinia kola on selected organs of the dog. Int. J. Morphol.,26(4):1069-1072, 2008.

SUMMARY: The ethanolic extract of Garcinia kola was administered to dogs to investigate the possible effects on selected organs of the dog. Two doses of the extract $(500 \mathrm{mg} / \mathrm{Kg}$ and $1000 \mathrm{mg} / \mathrm{Kg})$ were daily administered to the test animals for a period of 6 weeks. A dose related response was observed in the severity of histopathological changes observed in the testes, liver, kidney and small intestine of animals in the test groups. Despite the reported potentially beneficial effects of Garcinia kola, its use as a medicinal plant should be with great caution.

KEY WORDS: Garcinia kola; Dog; Histopathological effects.

\section{INTRODUCTION}

Plants are known to provide a source of inspiration for novel drug compounds and this is sequel to the fact that medicines derived from plants have made large contributions to human health and well being (Iwu et al., 1999). One of such is Garcinia kola, a plant in the family Guttiferae. The plant, which is found in moist forests grows up to a height of 12 meters (Iwu, 1993). It is referred to as "bitter kola" or "male kola" because of its bitter taste and the perceived aphrodisiac activity respectively (Uko et al., 2001). Traditionally, G. kola is regarded as a highly prized item and it is served to visitors in social gatherings as a mark of honour and also in the treatment of headache, cough, colic pains and gonorrhea (Iwu).

Scientifically, the potentials of G. kola as a therapeutic agent have been reported and these include hepato-protective (Iwu et al., 1987; Akintonwa \& Essien, 1990; Farombi et al., 2000; Nwankwo et al., 2000), antithrombotic (Olajide, 1999) and antibacterial (Ezeifeka et al., 2004).

However, despite the numerous reports of the potential beneficial therapeutic effects of $G$. kola, there have been some scientific reports adverse effects too. (Bradie \& Gill, 1990, Atawodi et al., 1995; Akinloye et al., 2000). This study was designed to investigate the possible adverse effects of prolonged administration of $G$. kola extract on selected organs of the dog.

\footnotetext{
${ }^{*}$ Faculty of Veterinary Medicine, University of Ibadan.

** Department of Chemistry, University of Ibadan.
}

\section{MATERIAL AND METHOD}

The fruits of G. kola were obtained from Oja-Oba market in Ibadan, Oyo State, Nigeria. The fruits were decoated and subsequently cut into small pieces so as to increase the surface area. The latter process increased the drying rate of the bitter kola that was carried out under the hot sun. The grinding of the dried pieces into fine powder followed this procedure. Using absolute ethanol as the solvent, extraction was carried out by using the Soxhlet extractor as described by Tairu et al. (1991).

A total of nine puppies weighing between 5 and $7 \mathrm{~kg}$ were used in this study. They were randomized into three groups E1, E2 and C with each group containing three animals. Groups E1 and E2 were the test animals while group $\mathrm{C}$ served as the control. The dogs were housed in the experimental canine unit of the Department of Veterinary Medicine, University of Ibadan and were fed on home cooked food three times daily. Clean and fresh water was provided $a d$ libitum. Each of the animals in Groups E1 and E2 was daily orally administered with $500 \mathrm{mg}$ and $1000 \mathrm{mg}$ of the semisolid extract of G. kola, respectively per kilogram body weight for a period of 6 weeks. Dogs belonging to group C were daily administered with $2 \mathrm{ml}$ of normal saline for the period of the study. Clinical parameters like rectal temperature, respiratory rate, heart rate and pulse rate were recorded daily for each of the animals. 
At the end of 6 weeks, all the animals were euthanised by the intravenous administration of Euthatal ${ }^{\circledR}$. Tissue samples were thereafter collected from the cerebrum, cerebellum, lymph nodes, lungs, heart, kidneys, adrenal glands, salivary glands, urinary bladder, testicles, small intestine, large intestine, pancreas, liver and spleen. These tissue samples were preserved in $10 \%$ neutral buffered formalin and were later processed using standard histopathological techniques.

\section{RESULTS}

There were no clinically obvious signs of ill health in any of the animals used in this study and no deaths were recorded. Clinical parameters recorded were within normal limits.

The livers of groups E1 and E2 dogs showed severe, widespread vacuolar degeneration of hepatocytes. There was multifocal centrilobular hepatocellular necrosis and mononuclear cell aggregations (Fig. 1). There was cellular infiltration including neutrophils, lymphocytes and macrophages, mild periportal fibrosis and Kupffer cell proliferation.

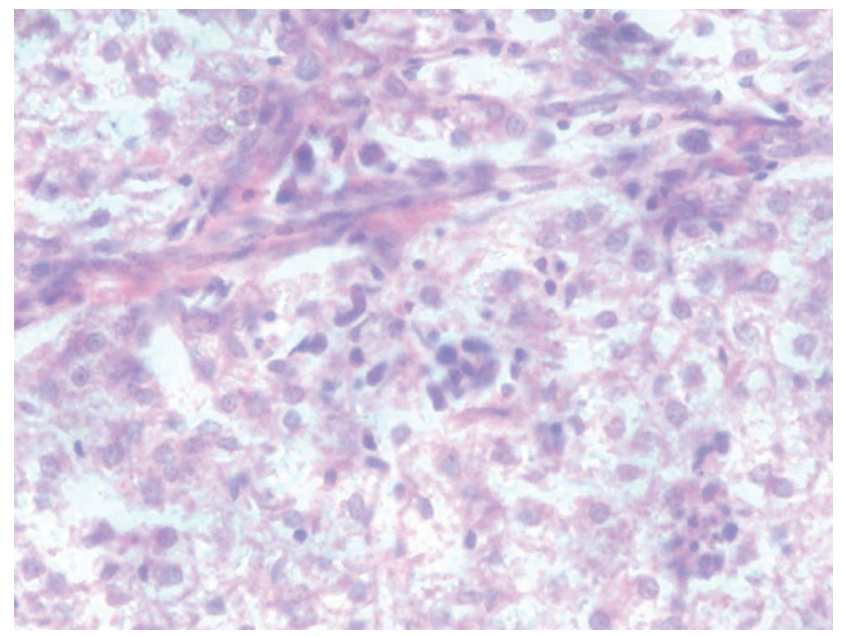

Fig. 1. Severe vacuolar degeneration and necrosis of hepatocytes, mononuclear cell aggregations and mild portal fibrosis in the liver of a dog given $1000 \mathrm{mg} / \mathrm{kg}$ of the extract of $G$. kola for 6 weeks (H\&E; $\mathrm{x} 450)$

In the kidneys, there were multiple focal areas of glomerular degeneration and coagulative necrosis of proximal tubules and focal mononuclear cell aggregations (Fig. 2). Also, there were pinkish tubular casts in the cortex and medulla.

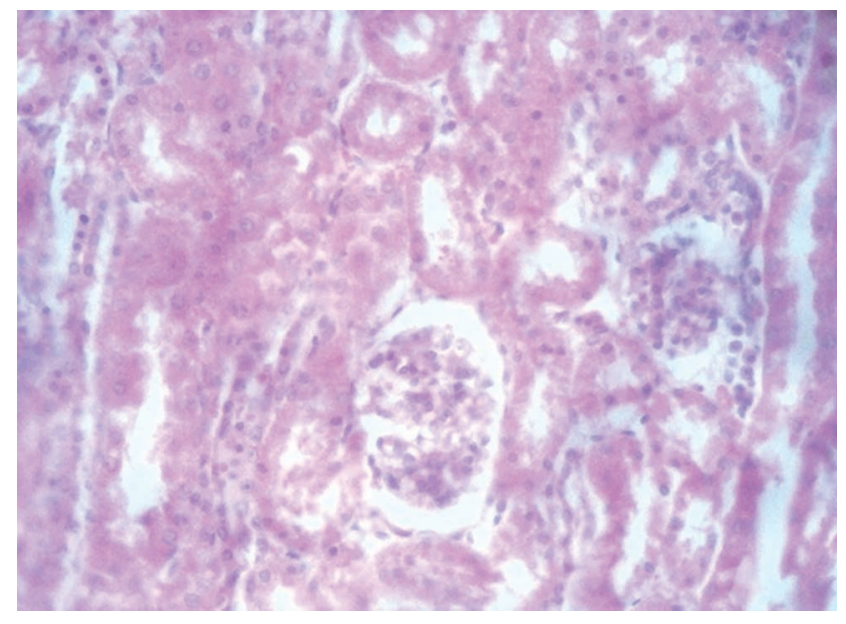

Fig. 2. Glomerular degeneration, tubular necrosis and mild interstitial mononuclear cell infiltration in the kidney of a dog given $500 \mathrm{mg} / \mathrm{kg}$ of the extract of G. kola for 6 weeks (H\&E; x450).

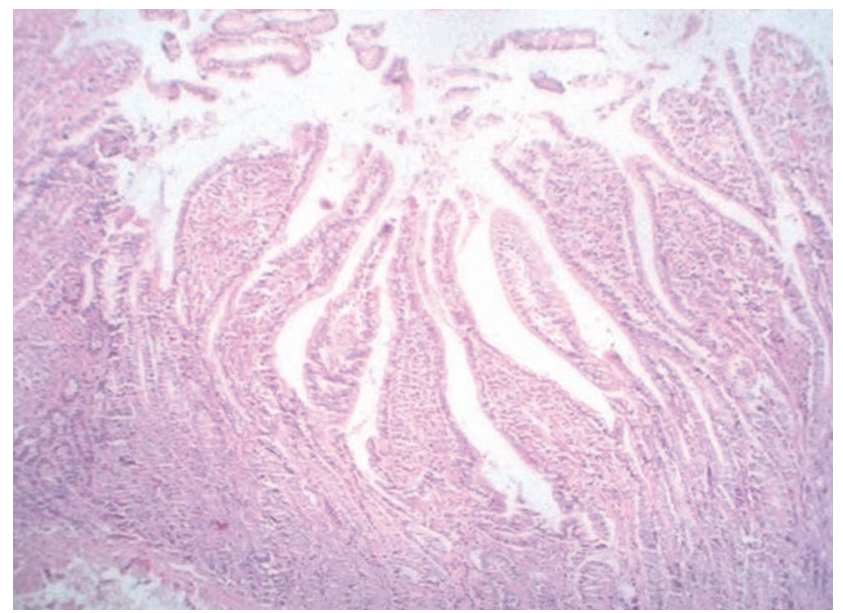

Fig. 3. Moderately severe villous collapse and mild goblet cell hyperplasia in the small intestine of a $\operatorname{dog}$ given $500 \mathrm{mg} / \mathrm{kg}$ of the extract of G. kola for 6 weeks (H\&E; x300)

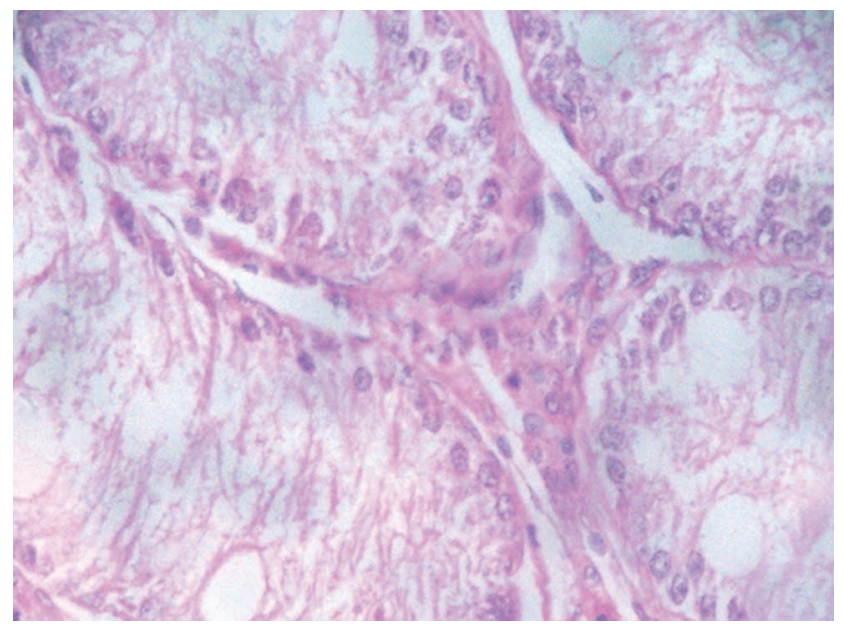

Fig. 4: Severe testicular hypoplasia in a dog given $500 \mathrm{mg} / \mathrm{kg}$ of the extract of $G$. kola for 6 weeks (Note the complete absence of viable spermatids and spermatozoa in the seminiferous tubules) (H\&E; x600) 
The small intestine showed mild villous atrophy, villi stunting, goblet cell hyperplasia (Fig. 3) and presence of scattered neutrophils and lymphocytes in the lamina propria and submucosa. These lesions were more severe in the group E2 animals.

In the testes of group E1 animals, about $70 \%$ of the seminiferous tubules were hypoplastic with disorganized epithelial cells and no viable spermatids and spermatozoa (Fig. 4). In the group E2 animals, the testes were observed to be severely fibrotic with no viable seminiferous tubules. There were no significant lesions in the other tissues examined for both the experimental and control groups of animals.

\section{DISCUSSION}

The degenerative changes observed in this study on the liver, kidney and small intestine are consistent with earlier reports on the effects of prolonged ingestion of G. kola (Virk \& Menke, 1986) These lesions observed in the liver might account for earlier findings in which the inhibition of hepatic metabolism of drugs in rats treated with the flavonoid extract of G. kola seeds was reported (Bradie \& Gill).

Also, the effect on the testes is consistent with earlier findings on the effect of prolonged administration of the aqueous extract of $G$. kola on rabbit testes (Akinloye et al.). Although G. kola is traditionally used as an aphrodisiac, the observed effects on histological sections of the testes of dogs in this study, as well as that reported in rabbit testes by Akinloye et al., both suggest a possible anti-fertility action. Braide et al., (2003) reported a marked reduction in the serum testosterone concentration of rats administered the methanolic extract of $G$. kola. This might have been as a result of the direct action of $G$. kola on the testicular tissue.

Uko et al. had earlier reported a decrease in body mass gain in rats fed $G$. kola and this; they associated with reduced feed consumption. Although weight gain was not measured in this work, lesions found in the intestines in this work could result in poor feed conversion and ultimately, a decrease in weight gain.

This study has shown that despite the reported potentially beneficial effects of $G$. kola, prolonged administration of the ethanolic extract of $G$. kola could be injurious to some body systems. The histopathological findings observed in the tissues that were sampled were observed to be dose related.

Further work is required to investigate the mechanisms by which G. kola exerts its effect on the organs studied and also, carefully weigh the potential effects of $G$. kola as a therapeutic agent against the reported adverse effects.

NOTTIDGE H. O.; OMOBOWALE T. O.; TAIWO V. O. \& OMOTOSO M. A Estudio histopatológico del efecto de los extractos etanólicos de los frutos de Garnicia kola en órganos seleccionados de perro. Int. J. Morphol., 26(4):1069-1072, 2008.

RESUMEN: Fue administrado a perros extracto etanólico de Garcinia kola, para investigar los posibles efectos sobre determinados órganos. Dos dosis del extracto $(500 \mathrm{mg} / \mathrm{Kg}$ y $1000 \mathrm{mg} / \mathrm{Kg}$ ) fueron administradas diariamente a los animales durante un periodo de 6 semanas. Se observó una relación de la dosis con la gravedad en la respuesta de los cambios histopatológicos observados en testículos, hígado, riñón e intestino delgado de los animales. A pesar de los informes sobre efectos potencialmente beneficiosos de Garcinia kola, su uso como planta medicinal debe ser con mucha precaución.

PALABRAS CLAVE: Garcinia kola; Perro; Efectos histopatológicos.

\section{REFERENCES}

Akinloye, A. K.; Igbarha, O. O.; Olaniyi, M. O.; Alaka, O. O. \& Oke, B. O. Preliminary investigation on the effects of Garcinia kola on rabbit testes and epididymes. Trop. Vet., 18:49-54, 2000.

Akintonwa, A. \& Essien, A. R. Protective effects of Garcinia kola seed extract against paracetamol induced hepatotxicity in rats. J. Ethnopharmacol., 29(2):207-11, 1990.
Atawodi, S. E.; Mende, P.; Pfundestein, B.; Preussmann,; R. $\&$ Spiegelhadler, B. Nitrosatable amines and nitrosamide formation in natural stimulants: Cola acuminata, $C$. Nitida and Garcinia kola. Food Chem. Toxicol., 33(8):625-30, 1995.

Bradie, V. B. \& Grill, V. Histological alterations by a diet containing seeds of Garcinia kola: Effect on liver, kidney and intestine of rat. Gengebaurs. Morphol. Jahrb., 136(1):95-101, 1990. 
NOTTIDGE, H. O.; OMOBOWALE, T. O.; TAIWO, V. O. \& OMOTOSO, M. A. Histopathological studies on the effects of the ethanolic extract of the fruits of Garcinia kola on selected organs of the dog. Int. J. Morphol.,26(4):1069-1072, 2008.

Bradie, V. B.; Agube, C. A.; Essien, G. E. \& Udoh, F. V. Effect of Garcinia kola seed alkaloid extract on levels of gonadal hormones and pituitary gonadotrophins in rat serum. Nig. J. Phys. Sci., 18(1-2):59-64, 2003.

Ezeifeka, G. O.; Orji, M. U.; Mbata, T. I. \& Patrick, A. O. Antimicrobial Activities of Cajanus cajan, Garcinia kola and Xylopia aethiopica on Pathogenic Microorganisms. Biotechnology, 3(1):41-3, 2004.

Farombi, E. O.; Tahnteng, J. G.; Agboola, A. O.; Nwankwo, J. O. \& Emerole G. O. Chemoprevention of 2acetylaminofluorene induced hepatotoxicity and lipid peroxidation in rats by kolaviron a Garcinia kola seed extract. Food Chem. Toxicol., 38(6):535-41, 2000.

Iwu, M. M. Handbook of African medicinal plants. CRC press, Boca Raton, 1993.

Iwu, M. M.; Igboko, O. A.; Onwuchekwa, U. A. \& Okunji, C .O. Evaluation of the antihepatotoxic activity of the biflavonoids of Garcinia kola seed. J. Ethnopharmacol., 21(2):121-38, 1987.

Iwu, M. M.; Duncan, A. R. \& Okunji, C. O. New antimicrobials of plant origin. In: J. Janick (ed). Perspectives on new crops and new uses. Alexandria, ASHS press, 1999. pp.457-62.

Nwankwo, J. O.; Tahnteng, J. G. \& Emerole, G. O. Inhibition of aflatoxin B1 genotoxicity in human liver-derived HepG2 cells by kolaviron biflavonoids and molecular mechanisms of action. Eur. J. Cancer Prev., (9):35-61, 2000.

Olajide, O. A. Investigation of the effect of selected medicinal plants on experimental thrombosis. Phytother. Res., 13(3):231-2, 1999.

Tairu, A. O.; Omotoso, M. A.; Oderinde, R. A. \& Bamiro, B. O. Studies on Oxidative Stability of Crude and Processed Yellow Nutsedge Tuber and Almond Seed Oils. J. Food Sci. Tech., 28: 8-11, 1991.

Uko, O. J.; Usman, A. \& Ataja, A. M. Some biological activities of Garcinia kola in growing rats. Veterinarski Arhiv., 71(5):287-97, 2001.

Virk, A. S. \& Menke, K. H. Occurrence and nutritional significance of tannins present in unconventional feeds in India. Anim. Res. Dev., 24:7-22, 1986.
Correspondence to:

Dr. T.O. Omobowale

Faculty of Veterinary Medicine

University of Ibadan

NIGERIA

E-mail bukitayo_omobowale@yahoo.com

Received: 08-08-2007

Accepted: 17-04-2008 